\title{
A review of the most important medicinal herbs affecting giardiasis
}

\author{
Mohamad Reza Nazer $^{\circledR}$, Saber Abbaszadeh ${ }^{2,3}$, Khatereh Anbari ${ }^{4}$, Morteza Shams $^{5^{*}(\mathbb{D}}$ \\ ${ }^{1}$ Department of Infectious Diseases, Lorestan University of Medical Sciences, Khorramabad, Iran \\ ${ }^{2}$ Student Research Committee, Lorestan University of Medical Sciences, Khorramabad, Iran \\ ${ }^{3}$ Razi Herbal Medicines Research Center, Lorestan University of Medical Sciences, Khorramabad, Iran \\ ${ }^{4}$ Community Medicine Department, Lorestan University of Medical Sciences, khorramabad, Iran \\ ${ }^{5}$ Zoonotic Diseases Research Center, Ilam University of Medical Sciences, Ilam, Iran
}

\section{A R T I C L E I N F O}

\section{Article Type:}

Review

\section{Article History:}

Received: 20 November 2018

Accepted: 24 December 2018

\section{Keywords:}

Infectious diseases

Parasitic diseases

Protozoa

Giardia

Medicinal plants

\begin{abstract}
A B S T R A C T
Infection due to the protozoa giardia is one of the most common parasitic infections in the world. Millions of people across the world acquire this infection each year. The most common clinical symptoms of giardiasis include abdominal pain, bloating and diarrhea, indigestion, epigastric pain, nausea, vomiting, and oily feces with bad smell. Drugs used for giardiasis lead to certain side effects, such as unpleasant taste in the mouth, gastrointestinal discomfort, nausea, headache and leukopenia. Considering the importance of giardiasis infection, it is essential to identify anti-parasitic herbal drugs to eliminate cystic and trophozoite types of this disease. Hence, this article is aimed to report the medicinal plants that are used in Iranian traditional medicine against giardiasis. The information in this review study was obtained from scientific articles indexed in databases such as ISI, PubMed, Scopus, SID, Magiran and Google Scholar that were retrieved using the search terms giardia, protozoa, herbs, extracts and essential oils. Medicinal plants such as Lavandula stoechas, Ferula assa-foetida, Tanacetum parthenium, Allium paradoxum, Chenopodium botrys, Carum copticum, Allium sativum, Artemisia annua, Allium ascalonicum, ZizIphora clinopodioides, Zataria multiflorahad, Eucalyptus globulus, Lippia beriandievi, Punica granatum are among the most important herbs used in Iranian herbal medicine as anti-giardiasis agents. These herbs are good candidates to produce natural and effective drugs for giardia.
\end{abstract}

Implication for health policy/practice/research/medical education:

This article presented useful information about anti-giardiasis plants which could help pharmacists and scientists in provision of new drugs.

Please cite this paper as: Nazer MR, Abbaszadeh S, Anbari K, Shams M. A review of the most important medicinal herbs affecting giardiasis. J Herbmed Pharmacol. 2019;8(2):78-84. doi: 10.15171/jhp.2019.13.

\section{Introduction}

Giardiasis is a parasitic disease caused by a flagellated protozoa called Giardia lamblia, Giardia intestinalis or Giardia duodenalis $(1,2)$. Infection caused by this parasite has been reported from all over the world, including various regions of Iran. Infection due to the Protozoa giardia is one of the most common parasitic infections in the world. Millions of people worldwide acquire this parasite every year (3). Transmission of this disease occurs through fecal-oral route, especially through contaminated food and water intake. The most important route of transmission is contaminated drinking water
(4). The incidence of this infection has been observed in children more than other age groups (5). Prevalence of giardiasis, as with most intestinal diseases, varies depending on the health status and is more common in temperate and tropical climates than cold regions $(6,7)$. The most common clinical symptoms of giardiasis include abdominal pain, bloating and diarrhea. Other symptoms include indigestion, epigastric pain, nausea, vomiting, and fatty stools with bad smell $(8,9)$.

Common medications for the treatment of this disease include nitroimidazole derivatives including tinidazole, ornidazole, metronidazole and nimorazole, benzimidazole 
derivatives such as mebendazole and albendazole, and other drugs such as quinacrine, furazolidone and paromomycin, among which metronidazole is a selective drug for the treatment of giardiasis. These drugs have unpleasant side effects such as an unpleasant taste in the mouth, gastrointestinal discomfort, nausea, headache and leukopenia. In addition, some of these drugs can lead to neurotoxic effects, restlessness, seizures and dizziness, and disrupt the process of the treatment. In addition, the mutagenic, carcinogenic, and adverse effects of some of them on the embryo have been demonstrated by studies on laboratory animals (10-12). As the giardiasis infection is transmitted and spread by cyst, different ways have been recommended to remove cyst, one of which is the use of plants and natural nutrients to eliminate the cyst of the parasite $(13,14)$. Medicinal plants and plant products have always been used to treat pain and illnesses from the old times (15-17), because when chemical drugs were not available, humans used these natural and accessible sources for treatment (18-21). Considering the importance of giardiasis, it is necessary to study the effect of anti-parasitic herbal drugs on the elimination of cystic and trophozoite forms of the disease. On the other hand, many herbal drugs have been discovered and used for the treatment of protozoan diseases. Therefore, it is particularly important to review such drugs, especially anti-giardia herbal drugs, because they can be used to produce effective natural drugs for this infectious agent. Hence, this article is aimed to report the medicinal plants that are used in Iranian traditional medicine against giardiasis

\section{Methods}

The information in this review study was obtained from scientific articles indexed in databases such as ISI, PubMed, Scopus, SID, Magiran and Google Scholar that were retrieved using the search terms giardia, protozoa, herbs, extracts and essential oils.

\section{Results}

Medicinal plants such as Lavandula stoechas, Ferula assa-foetida, Tanacetum parthenium, Allium paradoxum, Chenopodium botrys, Carum copticum, Allium sativum, Artemisia annua, Allium ascalonicum, ZizIphora clinopodioides, Zataria multiflorahad, Eucalyptus globulus, Lippia beriandievi, Punica granatum are among the most important herbs used in Iranian herbal medicine as antigiardiasis agents. The herbs with anti-Giardia properties are described below and summarized in Table 1.

\section{Lavandula stoechas $\mathrm{L}$}

This herbal plant belongs to Lamiaceae family. The results of the studies have shown that lavender plants are very effective in intravenous conditions and have a therapeutic potential for Giardia infection. So that the dose of 400 $\mathrm{mg} / \mathrm{mL}$ of hydroalcoholic extract of lavender is effective against Giardia lamblia (22).

\section{Ferula assa-foetida}

This herbal plant belongs to Apiaceae family. Alcoholic and aqueous extracts of Ferula assa-foetida had positive effects on Giardia lamblia cysts. The effect of fecundity of the alcoholic extract was greater than that of the aqueous extract. The percentage of fecundity of the alcoholic extract of Ferula assa-foetida was $37 \%$ at a concentration of $20 \mathrm{mg} / \mathrm{mL}$ and at the fourth hour it was $100 \%$. While the highest percentage of fecundity of the aqueous extract of Angus, at the same temperature and concentration in the fourth hour was $57.23 \mathrm{mg} / \mathrm{mL}$ (23). After 4 hours, the effect of the plant was $100 \%$.

\section{Tanacetum parthenium}

This herbal plant belongs to Asteraceae family. Based on the results of a study, chloroform extract of Tanacetum parthenium, at a concentration of $100 \mathrm{mg} / \mathrm{mL}$, was effective in the treatment of Giardia lamblia infection of Balb/C mice (24).

\section{Allium paradoxum}

This herbal plant belongs to Asteraceae family. Alcoholic hydroalcoholic extract of Allium paradoxum with $100 \mathrm{mg} /$ $\mathrm{mL}$ could eliminate Giardia lamblia cysts in Balb/C mice. Therefore, hydroalcoholic extracts of Allium paradoxum can be introduced as a natural anti-giardia compound (25).

\section{Chenopodium botrys $\mathrm{L}$}

This herbal plant belongs to Amaranthaceae family. The results of a study showed that the alcoholic and aqueous extracts of Turkish Chenopodium botrys seeds in vitro had a deleterious effect on Giardia lamblia cysts. The harmful effect of the alcoholic extract of this plant was greater than its aqueous extract. The effect of Turkish Artemisia alcoholic extract at a temperature of $37^{\circ} \mathrm{C}$, concentration of $20 \mathrm{mg} / \mathrm{mL}$, at fourth hour was $100 \%$. While the highest germination percentage of aqueous extract of Artemisia turkey with the same concentrations was 66.1 (26).

\section{Carum copticum}

This herbal plant belongs to Apiaceae family. The results of a study showed that its alcoholic extract as well as its essential oil had good effects on Giardia lamblia cysts under laboratory conditions. The results of this study showed that after 60 minutes contact of hydroalcoholic extract and essential oil on Giardia lamblia cysts, the MICs of Carum copticum were 100 and $8 \mathrm{mg} / \mathrm{mL}$, respectively (27).

\section{Allium sativum}

This herbal plant belongs to Amaryllidaceae family. It 
Table 1. Bioactive compounds of herbal plants

\begin{tabular}{ll}
\hline Scientific name & Active ingredients \\
\hline & \\
Lavandula stoechas L & $\begin{array}{l}\text { Flavonoids, phenolic acids, dipropenes, triplepenes, } \\
\text { tannins, materials as bitter, resins, saponin (22) }\end{array}$
\end{tabular}

Ferula assa-foetida

Tanacetum parthenium

Allium paradoxum

Chenopodium botrys L

Carum copticum

Allium sativum

Allicin (28)

Artemisia annua
Artemisinin (29)

Plant figure
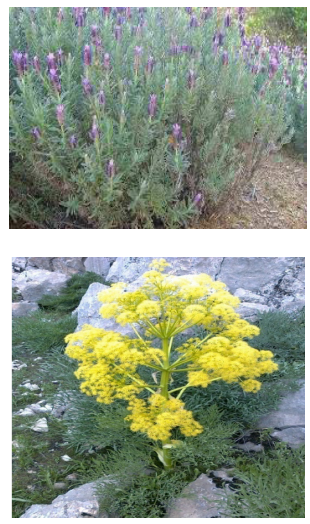

$\alpha$-Pinene, $\beta$-pinene, sabinene, eremophilene, $\beta$-caryophyllene and himachalen-7-ol (23)

Parthenolide (24)

Limonen, Spathulenol, alpha-Bisabolol, Z-Nerolidol, n-Tricosane, n-Docosane (25)

Linoleic acid, ferrozine (3-(2-pyridyl)-5,6-bis (4-phenyl-sulfonic acid)-1,2,4-triazine) (26)

Thymol, Trinin, Pinen and Myrcens (27)
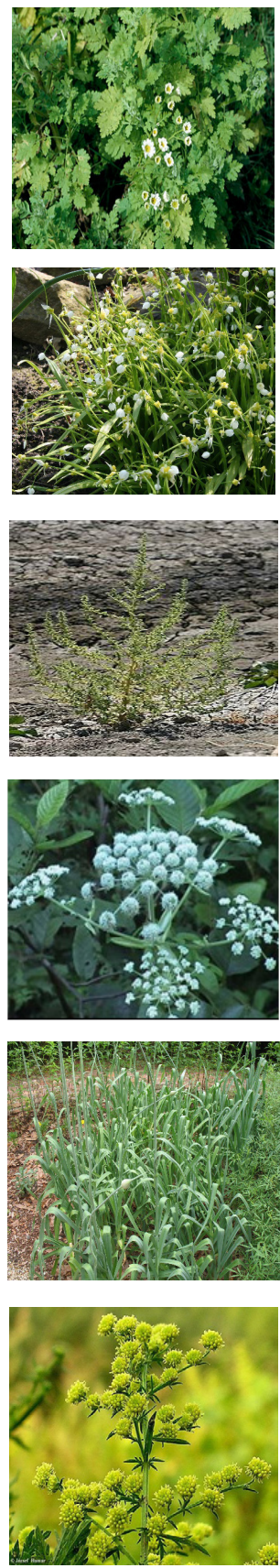
Table 1. Continued

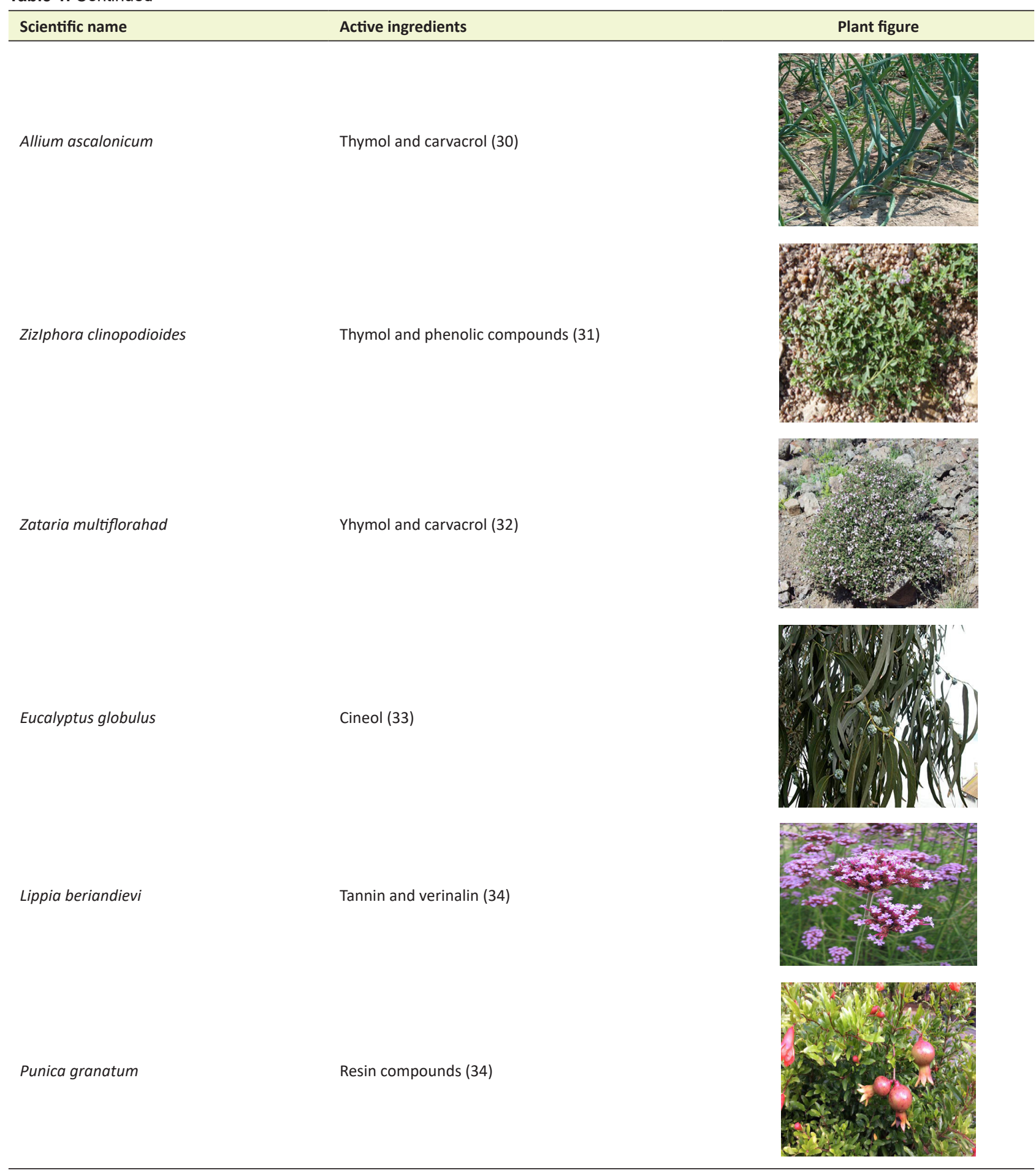

has been reported that Garlic extract is quite effective on Giardia cysts. Although the treatment of infected mice during 3 days at 20 and $40 \mathrm{mg} / \mathrm{kg}$ body weight of garlic extract did not completely improve all of the hair, the dose of $80 \mathrm{mg} / \mathrm{kg}$ of body weight during three days resulted in their complete recovery (28).

\section{Artemisia annua}

This herbal plant belongs to Asteraceae family. According to the results of a study, hydroalcoholic extract of Artemisia annua plant at a concentration of $100 \mathrm{mg} / \mathrm{mL}$ for 24 hours used as an effective compound for the elimination of giardia cysts (29).

\section{Allium ascalonicum}

The results of one study showed that Allium ascalonicum $(0.2 \mathrm{mg} / \mathrm{mL})$ inhibited Giardia. It is known that the main compounds of this plant are di sulfides (30). 


\section{ZizIphora clinopodioides}

The inhibitory dose of ZizIphora clinopodioides (zircia) has been reported to be $0.015 \mathrm{mg} / \mathrm{mL}$. It is known that the main compounds of this plant are thymol and phenols (31).

\section{Zataria multiflorahad}

a dose of $0.01 \mathrm{mg} / \mathrm{mL}$ of Zataria multiflorahad has had anti-Giardia effects. The main components of this plant are thymol and carvacrol (32).

\section{Eucalyptus globulus}

Eucalyptus (Eucalyptus globulus) at a dose of $0.022 \mathrm{mg} / \mathrm{mL}$ has had anti-Giardia effect due to the presence of active substances such as cineol (33).

\section{Lippia beriandievi}

The Lippia beriandievi plant at a dose of $0.85 \mathrm{mg} / \mathrm{mL}$ has shown to possess anti-Giardia effect due to the presence of substances such as tannins and verinalin (34).

\section{Punica granatum}

The pomegranate at a dose of $17 \mathrm{mg} / \mathrm{mL}$ has anti-Giardia effect due to its peppery content (31). The marked mango is composed of resin compounds. Based on the results of a study, it has been determined that mangoes with a dose of $212 \mathrm{mg} / \mathrm{mL}$ has anti-Giardia effect (34).

\section{Discussion}

Based on the results, medicinal plants such as Lavandula stoechas, Ferula assa-foetida, Tanacetum parthenium, Allium paradoxum, Chenopodium botrys, Carum copticum, Allium sativum, Artemisia annua, Allium ascalonicum, ZizIphora clinopodioides, Zataria multiflorahad, Eucalyptus globulus, Lippia beriandievi and Punica granatum are important herbs used in Iranian herbal medicine as antigiardiasis agents. In traditional medicine, Lavandula stoechas is used to treat the common cold, reduce blood pressure, treat headache, reduce stress, induce relaxation $(35,36)$. The plant contains active ingredients including flavonoids, phenolic acids, diterpenes, triterpene, tannins, bitter substances, resin, and saponin (37). Allium paradoxum has antiparasitic, antibacterial, anti-cancer and antioxidant effects (38-43). In traditional medicine, Chenopodium botrys has been used as an anti-parasitic plant (43). In traditional medicine, Carum copticum is used as carminative, anti-nausea, tonic, anthelmintic, diuretic and hypocholesterolemic plant, as well as an expectorant and spasm reliever. This plant serves as an appetite stimulant, and the fruit of the plant is traditionally used as a food flavoring (44). The plant contains compounds such as thymol, terpinene, phellandrene, pinene group, cymene group and myrcene, which are mainly oxygenated monoterpenes (45). Garlic is one of the medicinal plants that produce anti-parasitic and antimicrobial effects (46).
One of the important compounds of Allium sativum is allicin (47). In traditional medicine, Artemisia annua was used as an anti-parasite and anti-malarial agents (48-50). The most important compound that has been isolated from the Artemisia annua is artemisinin (51-60). Giardia is one of the most common gastrointestinal parasites that causes various personal and social problems. Drugs such as metronidazole, furazolidone and paramomycin are prescribed for giardia and its species. The exact mechanism actions of the medicinal plants are not clear. Metronidazole causes the death of microorganisms by preventing subsequent replication. Probably the herbal drugs and bioactive compounds of this study, through a mechanism similar to the metronidazole mechanism, caused the death of Giardia's parasite. It should be noted that polyphenols which are abundant in most of these plants have been shown to possess anti-giardiasis effects (31).

\section{Conclusion}

The medicinal plants can produce anti-parasitic effects due to their active ingredients and antioxidant compounds, and can be used as effective natural anti-giardiasis drugs.

\section{Authors' contributions}

All authors all contributed equally in planning and carrying out this study. All authors read the manuscript and confirmed the publication for final version.

\section{Conflict of interest}

None.

\section{Ethical considerations}

Not applicable.

\section{Funding/Support}

There is no financial support for this work.

\section{References}

1. Plutzer J, Ongerth J, Karanis P. Giardia taxonomy, phylogeny and epidemiology: Facts and open questions. Int J Hyg Environ Health. 2010; 213(5): 321-33 .

2. Saebi E. Porotozal diseases in Iran, Text book of clinical parasitology. 6th ed. Tehran: Hayan press; 1998: 81-95 .

3. Ankarklev J, Hestvik E, Lebbad $\mathrm{M}$, et al. Common coinfections of Giardia intestinalis and Helicobacter pylori in non-symptomatic Ugandan children. PLoS Negl Trop Dis. 2012; 6(8): 1780.

4. Karaby O, Tamer A. Treatment of Gardiasis. World J Gastroenterol. 2004;15(8):1215-17.

5. Savioli L, Smith H, Thompson A. Giardia and Cryptosporidium join the 'Neglected Diseases Initiative'. Trends Parasitol. 2006;22(5):203-8.

6. Thompson RC, Monis PT. Variation in Giardia implication for taxonomy and epidemiology. Adv Parasitoli 2004;58: 69-137.

7. Edrisian G, Rezaeean M, Ghorbani M, Keshavarz M, 
Mohebali M. [Medical protozoalogy]. 1st. Tehran: Tehran University of Sciences Publication; 2008. p. 175-6. [Persian].

8. Taherkhani H, Shariat i S, Abdolahi N, Roshandel GH. Clinical manifestations of giardiasis in Iran. J Clin Drug Res. 2009;3:1416-18 .

9. Escobedo AA, Almirall P, Robertson LJ, et al. Giardiasis: the ever-present threat of a neglected disease. Infect Disord Drug Targets. 2010;10(5):329-48.

10. Wright JM, Dunn LA, Upcroft P, Upcroft JA. Efficacy of antigiardial drugs. Expert Opin Drug Safety. 2003;2(6): 529-41.

11. Rossignol JF. Cryptosporidium and Giardia: Treatment options and prospects for new drugs. Exp Parasitol. 2010; 1)124):45-53.

12. Tejman Yarden N, Eckmann L. New approaches to the treatment of giardiasis. Curr Opin Infect Dis. 2011;24(5): 451-6.

13. Blanke $\mathrm{CH}$, Naisabha GB, Balema MB, Mbaruku GM, Heide L, Muller MS. Herba Artemisia eannuae tea preparation compared to sulfadoxine-pyrimethamine in the treatment of uncomplicated falciparum malaria in adults: a randomized double-blindclinical trial. Trop Doct. 2008;38(2):113-6.

14. Ebrahimzadeh MA, Nabavi SF, Nabavi SM, Eslami B. Antihemoltic and antioxidant activities of Allium pararadoxum. Cent Eur J Biol. 2010;5(3):338-345.

15. Tajallaie-Asl F, Mardani M, Shahsavari S, Abbaszadeh S. Menstruation phytotherapy according to Iran ethnobotanical sources. J Pharm Sci Res. 2017;9(6):986990 .

16. Abbaszadeh S, Nosrati Andevari A. Folklore medicinal plants used in liver disease: A review. International Journal of Green Pharmacy. 2018; 12: 3.

17. Moradi B, Abbaszadeh S, Shahsavari S, Alizadeh M, Beyranvand F. The most useful medicinal herbs to treat diabetes. Biomedical Research and Therapy. 2018;5(8): 2538-51.

18. Jamshidi-Kia F, Lorigooini Z, Amini-Khoei H. Medicinal plants: past history and future perspective. J Herbmed Pharmacol. 2018;7(1):1-7.

19. Nazarian-Samani Z, Sewell RD, Lorigooini Z, RafieianKopaei M. Medicinal plants with multiple effects on diabetes mellitus and its complications: a systematic review. Curr Diabetes Rep. 2018;18(10):72.

20. Bahmani M, Shirzad H, Mirhosseini M, Mesripour A, Rafieian-Kopaei M. A review on ethnobotanical and therapeutic uses of Fenugreek (Trigonella foenum-graceum L). J Evid Based Complementary Altern Med. 2016;21(1): 53-62.

21. Abbasi N, Azizi Jalilian F, Abdi M, Saifmanesh M. A comparative study of the antimicrobial effect of Scrophularia striata Boiss. Extract and selective antibiotics against Staphylococcus aureus and Pesudomonas aeruginosa. J Med Plants 2007;6(1):10-18.

22. Vazini H. The effect of lavender hydroalcoholic extract on cyst infection Giardia lamblia in mice. Journal of Neyshabour University of Medical Sciences 2017; 15; 5(2): 22-31.

23. Rezaee-Manesh MR, Shirbazou M. In-vitro the effect of dehydration of aqueous \& alcoholic extract on Giardia lamblia cyst. J Birjand Uni Med Sci. 2012;(1)19;22-33. [Persian].

24. Elmi T, Gholami SH, Azadbakht M, Ziaei H. Effect of chloroformic extract of Tanacetum parthenium in the treatment of Giardia lamblia infection in Balb/c Mice. J Mazandaran Univ Med Sci 2014;24(1):157-65. [Persian].

25. Elmi T, Gholami SH, Azadbakht M, Rahimi-Esboei B, Geraili Z. The effects of hydroalcoholic extract of leaves and onion of Allium paradoxum on Giardia lamblia in mice. J Shahrekord Univ Med Sci. 2014;16(5):13-22. [Persian].

26. Rezaeemanesh M, Shirbazoo S, Pouryaghoub N. In-vitro giardicidal effects of aqueous and alcoholic extracts of Chenopodium botrys L. on Giardia lamblia cysts. Journal of Torbat Heydarieh Faculty of Medical Sciences. 2013;1(1): 3-6. [Persian].

27. Shahabi S, Ayazi Rozbahani F, Kamalinejad M, Abadi AR. Investigation on the effect of germination of extract and essential oil of grasshopper on Giardia lamblia cyst in experimental conditions. Res Med. 2008;32(4):303-7.

28. Safar Harandi MM, Dalimi Asl A, Ghaffarifar F. In vitro and in vivo effects of garlic (Allium sativum) extract on Giardia lamblia and Giardia muris. Hakim Res J. 2006;9(3):58-64.

29. Rahimi-Esboei B, Gholami S, Azadbakht M, Ziaei H. Effect of hydroalcoholic extract of Cotonga (Artemisia annua) on cystic stage of Giardia lamblia parasite in laboratory conditions. Mazandaran Uni Med Sci J. 2012;90(22):72-80. [Persian].

30. Azadbakht M, Sajjadi S.M, Rostami J. Giardiacidal activity of three Allium species on Giardia intestinal is cysts. Iran J Basic Med Sci. 2003;3:184-8.

31. Bahri Najafi R, Motazedian M, Azadbakht M, Sodagar R. Effect of essential oils from some medicinal plants on Giardia lamblia cyst in comparison with metronidazole. Esfehan Univ Res J. 2003;17(2):199-206. [Persian].

32. Farsangi M, Sahebani N, Movahed A, Tahmasbi R, Rayani M. Effect of Thymus vulgaris on Giardia lamblia cyst (In vitro). J Teb Jonoob. 2001;4(2):88-95.

33. Saiedi A. Evaluation of some essences from medicinal plants on Giardia lamblia and Entamoeba histolytica cysts as in vitro [thesis]. Shiraz: Shiraz Univ Med Sci; 1999. [Persian].

34. Ponce $\mathrm{MH}$, Navarro A, Martines GM, Alverez CR. In vitro effect of 14 plant extracts against Giardia lambellia. Rev Iinvest Clin. 1994;44(5):343-7.

35. Berrington $\mathrm{D}$, Lall $\mathrm{N}$. Anticancer activity of certain herbs and spices on the cervical epithelial carcinoma (HeLa) cell line. Evid Based Complement Alternat Med. 2012;2012: 564927. doi: 10.1155/2012/564927

36. Messaoud C, Chograni H, Boussaid M. Chemical composition and antioxidant activities of essential oils and methanol extracts of three wild Lavandula L. species. Nat Prod Res. 2012; 26(21):1976-84.

37. Zamanian-Azodi M, Rezaie-Tavirani M, Heydari-Kashal S, Kalantari S, Dailian S, Zali H. Proteomics analysis of MKN45 cell line before and after treatment with Lavender aqueous extract. Gastroenterol Hepatol Bed Bench. 2012;5(1):35-42.

38. PackiaLekshmi NCJ, BenarcinSumi S, Viveka S, Jeeva S, Raja Brindha J. Antibacterial activity of nanoparticles from Allium sp. J Microbiol Biotech Res. 2012;2 (1):115-9.

39. Sarkari B, Nadin H, Asgarian S, Farnia A, Asgarian M. the 
effect of garlic on the growth of Trichomonas vaginalis. J Gorgan Univ Med Sci. 2009;11(3):13-7. [Persian].

40. Mehrabi M, Sadraei J, Ghafarifar F. The effects of garlic on the oocyst of cryptosporidium parvum in HANK medium. J Kordestan Univ Med Sci. 2011;17(1):53-60. [Persian].

41. Radwan A, Khalil I, Wahdan E. In vitro evaluation of antihelmintic activity of Allium sativum against adult Cotylophoron cotylophorum (Paramphistomidae). J Egypt Parasitol United. 2012;5(2):135-46.

42. Ebrahimzadeh MA, Nabavi SF, Nabavi SM, Eslami B. Antihemoltic and antioxidant activities of Allium pararadoxum. Centr Eur J Biol. 2010;5(3):338-45.

43. Sistanie A. Iranian folk medicine. 1st ed. Tehran: Rozaneh press; 1991. [Persian].

44. Zargari A. Medicinal plants. Tehran: Tehran publication; 1992. p. 36. [Persian].

45. Nagulakshmi S, Shankaracharya NB, Naik JP, Rao LJM. Studies on chemical and technological aspects of ajowan aspects (Trachyspermum ammi). J Food Sci Techol Mysore. 2000;39:277-81.

46. Sharma VD. Antibacterial property of Allium sativum in vitro and in vivo study. India J Exp Biol. 1977;15:466-8.

47. Soffar SA, Mokhtar GM. Evaluation of antiparasitic effects of aqueous garlic extract in hymenolepiasis and giardiasis. Parasitology. 1991;21:497-502.

48. Bilia AR, Melillo de Malgalhães P, Bergonzi MC, Vincieria FF. Simultaneous analysis of artemisinin and flavonoids of several extracts of Artemisia annua L. Obtained from a commercial sample and a selected cultivar. Phytomedicine. 2006;13:487-493.

49. Azadbakht M, Azadbakht MS. Five prevalent antiprotozoal herbal drugs. J Mazandaran Univ Med Sci. 2008;18(67):118132.

50. Cai Y, Luo Q, Sun M, Corke H. Antioxidant activity and phenolic compounds of 112 traditional Chinese medicinal plants associated with anticancer. Life Sci.74:2157-84;2004 .

51. Azadbakht MH, Ziaei H, Abdollahi F, Shabankhani B. Effect of essential oils of Artemisia, Zataria and Myrtus commonis on Trichomonas vaginalis. J Med Plant. 2003;8)2 ):35-40.

52. Sharif M, Ziaei H, Azadbakht M, Daryani A, Ebadattalb A, Rostami M. Effect of methanolic extract of Artemisia auchori and Camellia sinansis on Leishmania major (in vitro). Turk Sci. 2006;36 (6):365-9.

53. Blanke $\mathrm{CH}$, Naisabha GB, Balema MB, Mbaruku GM, Heide L, Müller MS. Herba Artemisiae annuae tea preparation compared to sulfadoxine-pyrimethamine in the treatment of uncomplicated falciparum malaria in adults: a randomized double-blind clinical trial. Trop Doct. 2008;38(2):113-6. doi: 10.1258/td.2007.060184.

54. Moayeri A, Azimi M, Karimi E, Aidy A, Abbasi N. Attenuation of morphine withdrawal syndrome by Prosopis farcta Extract and its bioactive component luteolin in comparison with clonidine in rats. Medical Science Monitor Basic Research. 2018;24:151-8.

55. Bahmani M, Khaksarian M, Rafieian-Kopaei M, Abbasi N. Overview of the therapeutic effects of Origanum vulgare and Hypericum perforatum based on Iran's ethnopharmacological documents. Journal of Clinical and Diagnostic Research. 2018;12 (7):1-4.

56. Tajbakhsh M, Karimi A, Tohidpour A, Abbasi N, Fallah F, Akhavan MM. J Microbiol. The antimicrobial potential of a new derivative of cathelicidin from Bungarus fasciatus against methicillin-resistant Staphylococcus aureus. J Microbiol. 2018;56(2):128-37. doi: 10.1007/s12275-0187444-5.

57. Abbasi N, Mohammadpour S, Karimi E, Aidy A, Karimi P, Azizi M, et al. Protective effects of Smyrnium cordifolium Boiss essential oil on pentylenetetrazol-induced seizures in mice: involvement of benzodiazepine and opioid antagonists. J Biol Regul Homeost Agents. 2017;31:683-9.

58. Faryadian S, Sydmohammadi A, Khosravi A, Kashiri M, Faryadayn P, Abasi N. Aqueous extract of Echium amoenum elevate CSF serotonin and dopamine level in depression rat. Biomed Pharmacol J. 2014; 7(1). doi:10.13005/bpj/463.

59. Shamsi M, Shahsavari S, Abbasi S. A Review of the most important medicinal herbs affecting leishmaniasis and ulcers in Iranian pharmacy knowledge. J Pharm Sci Res. 2018;9:1.

60. Shokri Z, Khoshbi M, Koohpayeh A, Abbasi N, Bahmani F, Rafieian-Kopaei M, et al. Thyroid diseases: Pathophysiology and new hopes in treatment with medicinal plants and natural antioxidants. Intern J Green Pharmacy. 2018;12(3):473-83. Doi:10.22377/ijgp.v12i03.2007 